\title{
Leukocyte Cell Clumps Measurement
}

National Cancer Institute

\section{Source}

National Cancer Institute. Leukocyte Cell Clumps Measurement. NCI Thesaurus. Code C92246.

The determination of the amount of leukocyte cell clumps present in a sample. 